\title{
Bartholin's gland adenoma in a Saanen goat
}

\author{
Jessica Regina Moreira ${ }^{1}$ Thalita Evani Silva de Oliveira ${ }^{1}$ Eriky Akio de Oliveira Tongu $^{2}$ \\ Raissa Oliveira Leite ${ }^{2}$ Geison Morel Nogueira ${ }^{2}$ Mariana de Mello Zanim Michelazzo ${ }^{1}$ \\ Diego José Zanzarini Delfiol ${ }^{2}$ João Paulo Elsen Saut ${ }^{2}$ Selwyn Arlington Headley ${ }^{13^{*}}$
}

\footnotetext{
${ }^{1}$ Laboratório de Patologia Animal, Departamento de Medicina Veterinária Preventiva, Universidade Estadual de Londrina (UEL), Londrina, PR, Brasil.

${ }^{2}$ Faculdade de Medicina Veterinária, Universidade Federal de Uberlândia (UFU), Uberlândia, MG, Brasil.

${ }^{3}$ Laboratório multi-usário em Saúde Animal, Unidade de Processamento Orgânico, Departamento de Medicina Veterinária Preventiva, Universidade Estadual de Londrina (UEL), 86057-970, Londrina, PR, Brasil. E-mail: selwyn.headley@uel.br. "Corresponding author.
}

\begin{abstract}
Tumors affecting Bartholin's gland are considered rare in human medicine; there are few reports in the veterinary literature, with descriptions occurring only in cows. This article described the clinical and pathological findings associated with Bartholin's gland adenoma in a goat. Clinically, a 7-year-old pregnant Saanen goat presented bilateral enlargement of the vulva that did not regress spontaneously after parturition. Grossly, these vulvar masses were multilobulated, contained cystic areas from which oozed a whitish fluid. Histopathology revealed an adenoma characterized by the proliferation of irregularly shaped neoplastic epithelial cells that formed tubular to glandular-like structures. These neoplastic cells demonstrated moderate anisokaryosis and evident nucleoli. The intratumoral proliferation index (PI) was estimated by immunoreactivity with the protein ki-67. Further, the glandular-like structures produced a Periodic Acid-Schiff positive secretion. A diagnosis of Bartholin's gland adenoma was established due to the anatomic location of the neoplastic growths, the histopathological features, and the PI of the tumor.

Key words: Histopathology, ki-67 protein, adenoma, major vestibular glands.
\end{abstract}

Adenoma de glândula de Bartholin em cabra da raça Saanen

RESUMO: Tumores que afetam a glândula de Bartholin são considerados raros em humanos e há poucos relatos na medicina veterinária, sendo descrito somente em vacas. Este artigo descreve os achados clínicos e patológicos associados ao adenoma na glândula de Bartholin em uma cabra. O animal da raça Saanen, com sete anos de idade e gestante apresentava aumento de volume bilateral na região da vulva, que não regrediu após o parto. Macroscopicamente, a massa era multilobulada, com presença de vários cistos preenchidos por uma secreção esbranquiçada. A histopatologia revelou um adenoma, caracterizado por proliferação de células epiteliais de formato irregular que formavam estruturas tubulares semelhantes à glândulas. Estas células neoplásicas apresentavam anisocariose moderada e nucléolos evidentes. O indice de proliferação celular intratumoral (PI) foi estimado por imunorreatividade à proteína ki-67. Além disso, a secreção produzida por essas estruturas do tipo glandular, foi positiva na coloração do Ácido Periódico-Schiff. O diagnóstico de adenoma da glândula de Bartholin foi estabelecido pela localização anatômica dos tumores neoplásicos, características histopatológicas e à PI do tumor.

Palavras-chave: histopatologia, ki-67, adenoma, glândulas vestibulares maiores.

\section{INTRODUCTION}

Bartholin's gland (BG), also known as the major vestibular glands or Bartholin gland, are bilateral, mucus-secreting, tubuloacinar glands located within the submucosa of the vulva of ruminants
(SCHLAFER \& FOSTER, 2016), cats (BACHA \& WOOD, 1990), and women (CARDOSI et al., 2001; LEE et al., 2015). Although, in veterinary medicine pathological alterations associated with this gland are not frequently reported, there are descriptions of cysts (FATHALLA et al., 1978; BADEMKIRAN et al., 2009; 
SCHLAFER \& FOSTER, 2016), and adenocarcinoma of the BG (TANIMOTO et al., 1994) in cow; cases of BG cysts or tumors in goats were not located when major databases were accessed. In human medicine, cysts are common complications of the BG (OMOLE et al., 2003; SOŚNIK et al., 2007) while malignant neoplastic growths of the $\mathrm{BG}$ are considered as rare and represent only $2 \%$ to $7 \%$ of all vulvar carcinomas (CARDOSI et al., 2001; LEE et al., 2015). Furthermore, due to the few diagnosed cases of benign lesions of the BG in human pathology (HELLER \& BEAN, 2014), probably associated with under reporting (SANTOS et al., 2006), the occurrence of benign neoplastic growths of this gland, such as nodular hyperplasia, adenoma, adenomyoma, and papilloma might be more reduced when compared with malignant neoplasia of the BG, including adenoid cystic carcinoma, squamous cell carcinoma, lymphoepithelioma-like carcinoma, and vulvar leiomyosarcoma (HELLER \& BEAN, 2014; LEE et al., 2015).

Bartholin's gland tumors are classified by The World Health Organization (WILKINSON \& TEIXEIRA, 2003) as adenomas and carcinomas, with most neoplasms arising from the mucin-secreting columnar epithelial cells of the acini and the squamous epithelium at the vestibular orifice of the ducts of the BG (FINAN \& BARRE, 2003; WILKINSON \& TEIXEIRA, 2003). This paper describes the clinical and pathological findings associated with Bartholin's gland adenoma in a Saanen goat, and represents the first description of this tumor in this species of domestic animal.

\section{MATERIALS AND METHODS}

\section{Clinical history}

A 7-year-old, pregnant, Saanen goat with a clinical history of bilateral enlargement of the vulva for one week was examined at the Veterinary Teaching Hospital, Universidade Federal de Uberlândia, Minas Gerais, Midwest Brazil in mid-September 2015. Gynecological evaluations revealed symmetrical enlarged masses $(4.5 \times 8 \times$ $9 \mathrm{~cm}$ ), of soft consistency that contained several nodular structures at the vulvar region of the goat (Figure 1). These masses inflicted discrete pain to the goat but without an increase in body temperature.
Further, the protruding masses prevented closure of the labia, and there was hyperemia of the vulvar mucosa, vaginitis with discrete accumulation of purulent secretion and a closed cervix. Ultrasonography (US) revealed circular anechoic structures (4 to $8 \mathrm{~mm}$ diameter), surrounded by $6 \mathrm{~mm}$ of isoechoic and externally located thinner hyperechoic tissue. All clinical parameters were normal, adjacent lymph nodes were not affected, and there was no clinical evidence of additional neoplastic growths in this goat.

Six days thereafter, the goat gave birth to a yeanling without any veterinary intervention. A clinical evaluation done seven days after kidding revealed that the enlarged vulvar masses were predominantly nodular, firm, with a distinct cystic pattern and inflicted moderate pain to the goat. A second US evaluation revealed several rounded, multifocal to coalescent anechoic structures, varying from 6 to $14 \mathrm{~mm}$, that were externally surrounded by an isoechoic $4 \mathrm{~mm}$ thickened tissue, which in turn was surrounded by hyperechoic tissue. These masses were surgically removed, fixed in $10 \%$ buffered formalin solution, and submitted for routine histopathological evaluation.

\section{Histopathology and immunohistochemistry}

Tissue fragments were stained by the Hematoxylin and Eosin (H\&E); selected fragments of the growth were evaluated with the Periodic Acid-Schiff (PAS) histochemical stain and used in an immunohistochemical (IHC) assay designed to determine the proliferation index (PI) by identify the proliferating protein ki-67 as described. For IHC, the anti-ki-67 antibody (MIB-1; Immunotech, Monrovia, California, USA) was diluted (1:50) and anti-cytokeratin pan monoclonal (PAN-CK, Invitrogen Life Technologies, Frederick, USA) was diluted (1:100), incubated overnight at $4^{\circ} \mathrm{C}$, after which chromogen developing was performed with 3,3'-diaminobenzidine (DAB, Invitrogen Life Technologies, Frederick, USA). The ki-67 slides were read by two observers, counting positive and negative nuclei (total of 500 neoplastic cells) in 12 representative fields with the $40 x$ objective. Only strong immunoreactive nuclei 


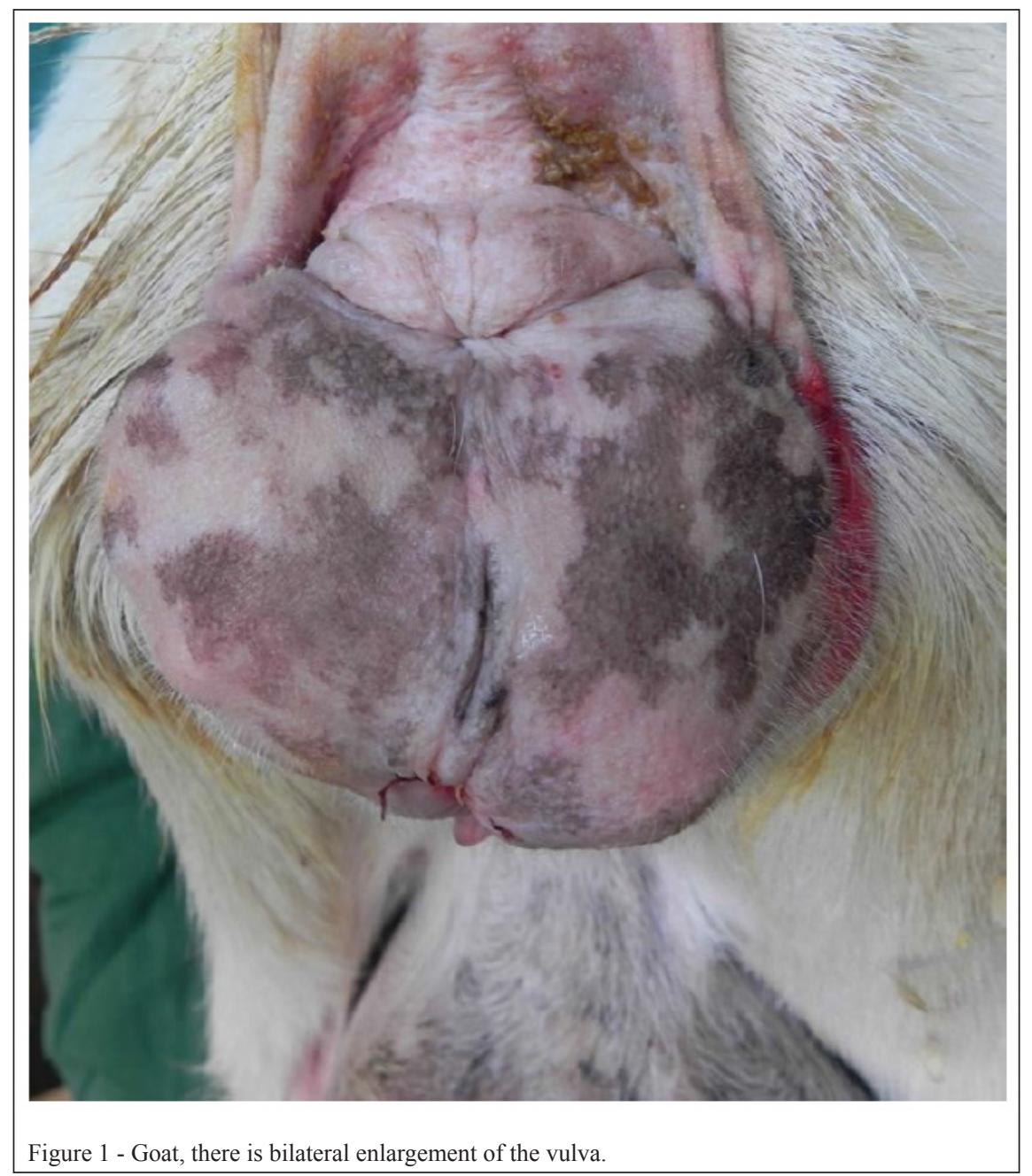

were considered as positive. The PI or the proportion of positive neoplastic cells in each field was calculated as described (CARVALHO et al., 2016).

\section{RESULTS}

Grossly, the vulvar masses $(2.5 \times 4 \times$ $6 \mathrm{~cm} ; 2.5 \times 3.5 \times 5.5 \mathrm{~cm})$ were multilobulated, with several cystic areas that contained a whitish fluid. The histopathological features of both masses were similar with discrete differences, and revealed tumorous growths formed by the proliferation of irregularly shaped neoplastic epithelial cells that formed tubular to glandular-like structures of different sizes and shapes, separated by variable septa of fibrous connective tissue. Most of these glandularstructures were dilated with a central accumulation of an eosinophilic amorphous material admixed with cellular debris (Figure 2). The neoplastic epithelial cells were small, cuboidal or elongated, with moderate cytoplasm, moderate anisokaryosis, homogeneous chromatin and with several evident nucleoli. Further, there were moderate areas of hemorrhage within the neoplastic proliferation, and the expansive growth of these epithelial tubular to glandular-like structures resulted in compression to the adjacent muscular tissue, surrounded by a thin capsule of fibrous connective tissue.

Cytokeratin revealed strong diffused immunoreactivity on all acini (Figure 3). The intratumoral PI, as determined by ki-67 


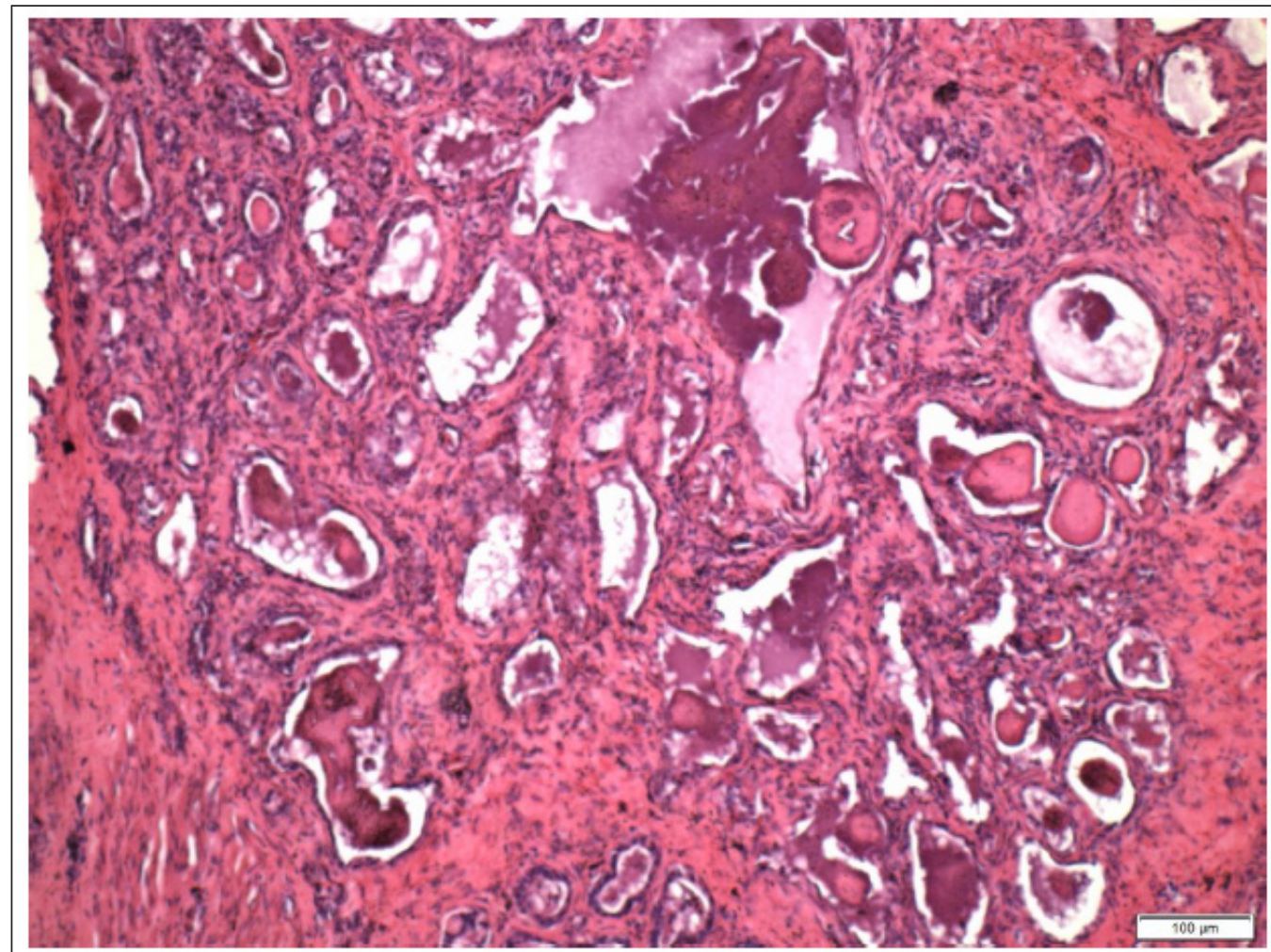

Figure 2 - Goat, vulva, Bartholin's gland adenoma; histopathological demonstration of the irregular tubular shaped tubular structures separated by fibrous septa. Hematoxylin and Eosin stain, Bar $=100 \mu \mathrm{m}$.

immunoreactivity was $12 \%$ (Figure 4 ). In addition, the glandular-like structures contained a PASpositive secretion (mucin); the cribriform pattern was not observed.

\section{DISCUSSION AND CONCLUSION}

The histopathological and the IHC findings observed in this case associated with the anatomical location of the masses are consistent with a description of BG adenoma (TANIMOTO et al., 1994; FINAN \& BARRE, 2003; WILKINSON \& TEIXEIRA, 2003; LEE et al., 2015), and probably represent the first presentation of this tumor in goats. In human pathology, a diagnosis of BG adenoma is based on several criteria: a) the anatomical location of the neoplastic growth; b) absence of a simultaneous primary tumor, and c) the histological elements of the neoplastic growth
(CARDOSI et al., 2001; FINAN \& BARRE, 2003; LEE et al., 2015); these features were observed in the case herein described. Since, there are no published data in the veterinary literature relative to the values to classify the ki-67 value obtained from a reproductive neoplastic growth, the results of this study were compared with the PI nodular hyperplasia of $\mathrm{BG}$ as described in women (SANTOS et al., 2006).

Bartholin's gland tumors must be differentiated from ectopic mammary tissue of goats (GAMEEL et al., 1992). In the case herein described, there was no spontaneous regression of the vulvar masses after parturition; spontaneous regression and the histological appearance of mammary gland tissue at the vulvar are the hallmarks of the ectopic glandular tissues described in Nubian and Syrian goats (GAMEEL et al., 1992). Although, there are few descriptions of lesions associated with Bartholin's 


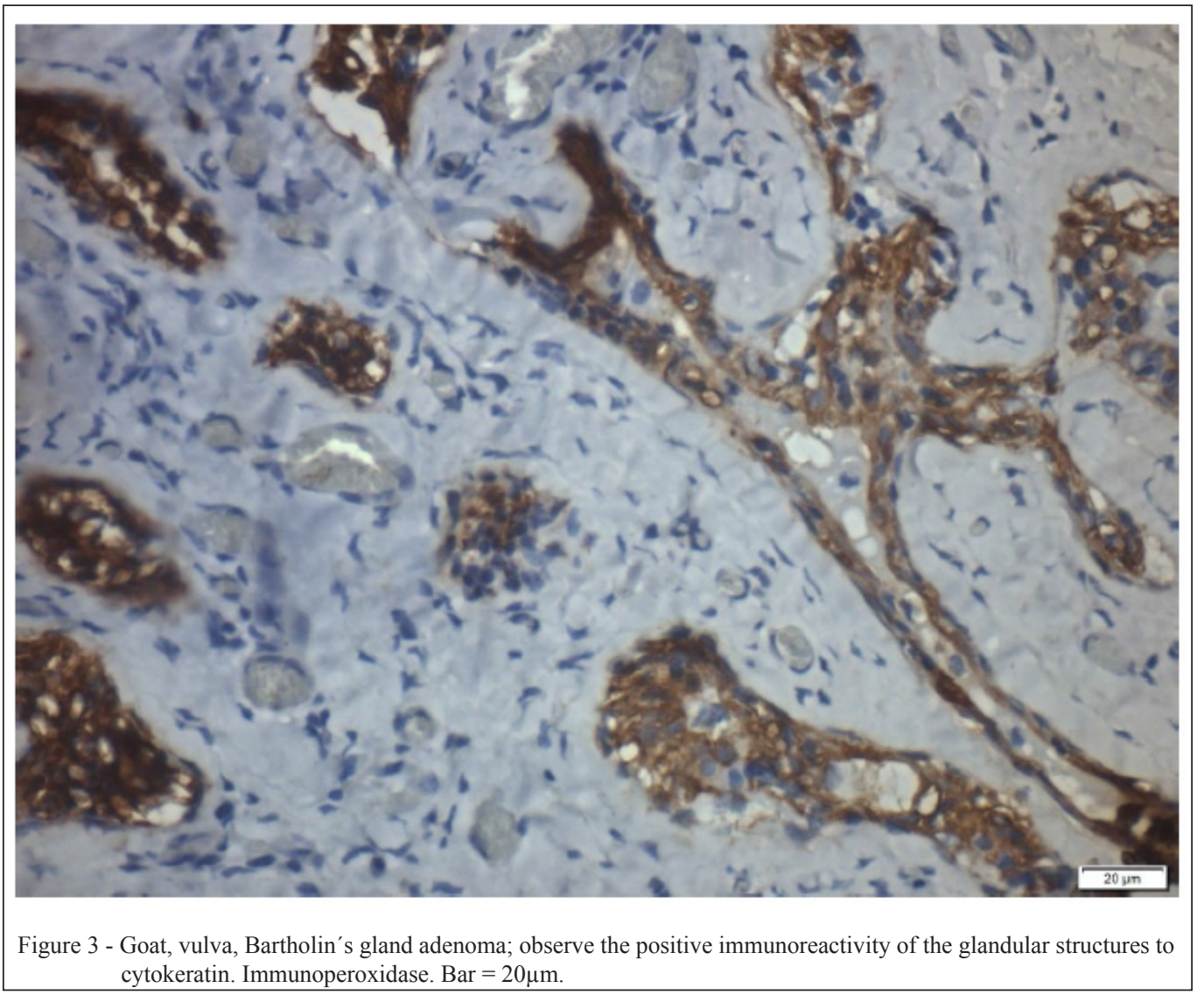

gland in veterinary medicine, reports of cysts (TANIMOTO et al., 1994; BADEMKIRAN et al., 2009; MANOKARAN et al., 2014; SCHLAFER \& FOSTER, 2016) and a adenocarcinoma (TANIMOTO et al., 1994) were identified in cows. All reported cases of Bartholin's gland lesions in cows were unilateral (FATHALLA et al., 1978; TANIMOTO et al., 1994; BADEMKIRAN et al., 2009; MANOKARAN et al., 2014); the case herein described was bilateral. Further, the PAS stain suggest that the glandular part of the tumor produced a glycoprotein; similar histopathological findings were described in a cow (TANIMOTO et al., 1994). In human medicine, BG tumors are thought to arise from the mucin-secreting columnar glandular epithelial cells (FINAN \& BARRE, 2003; WILKINSON \& TEIXEIRA, 2003), or from the squamous epithelium of the vestibular orifice (FINAN \& BARRE, 2003; HELLER \& BEAN, 2014 ); in this case the neoplastic growth probably originated from proliferated glandular epithelial cells.
Although, this tumor did not affect parturition directly, the lesion at the labia makes the organ susceptible to the entry of feces and contamination, which can result in an initial inflammation and terminate in vulvovaginitis (FATHALLA et al., 1978; BADEMKIRAN et al., 2009). In human medicine, the factors that contribute to the development of this tumorous growth are not completely elucidated, but a rare blood type was described in women diagnosed with this tumor (SOŚNIK et al., 2007), while inflammatory changes or infection might not be associated with carcinogenesis (LEUCHTER et al., 1982).

In conclusion, a diagnosis of $\mathrm{BG}$ adenoma was obtained due to the histopathological features of the tumor, the intratumoral PI, and the anatomical location of the masses. This report probably represents the first description of a Bartholin's gland tumor in goats. 


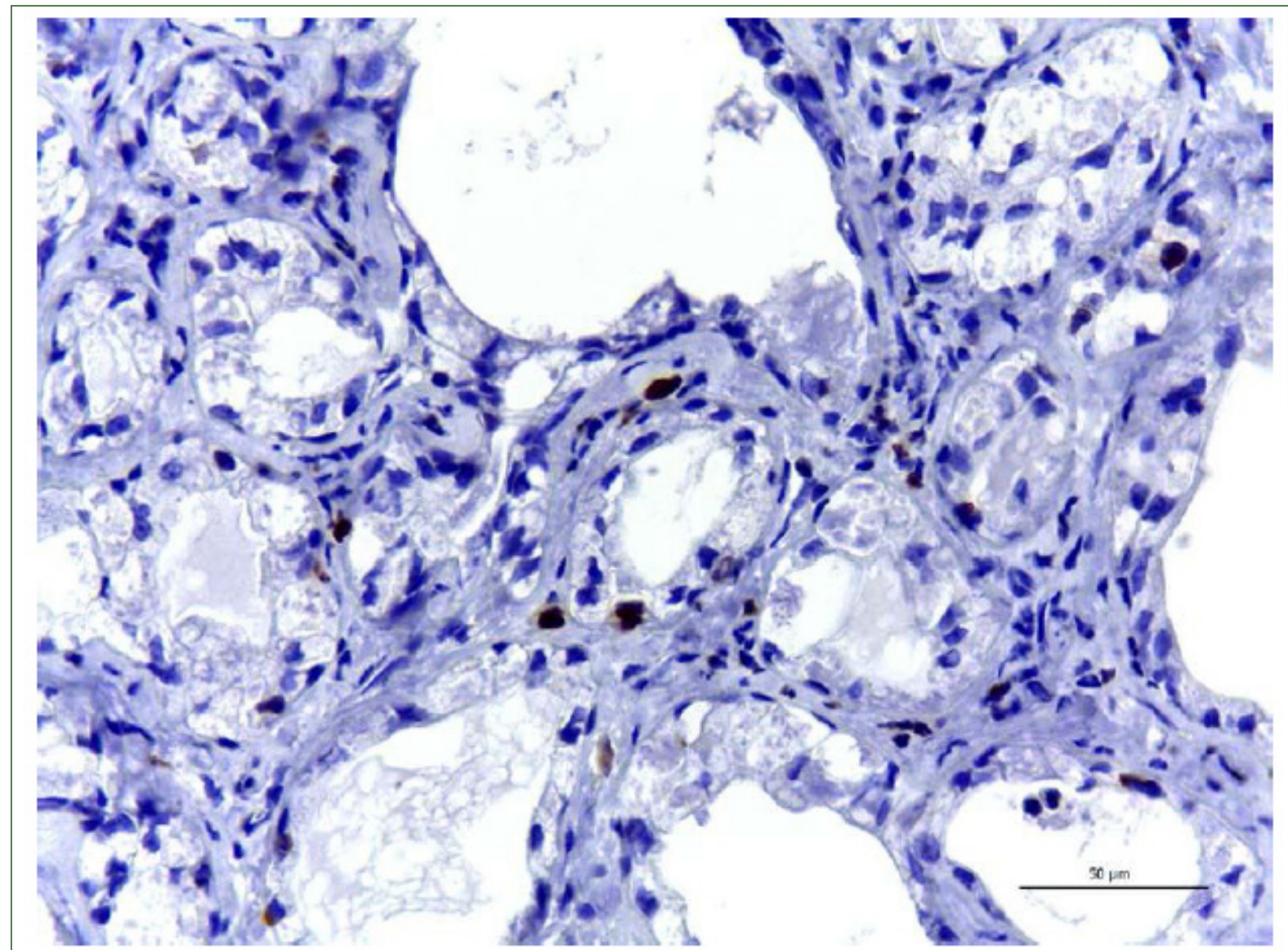

Figure 4 - Goat, vulva, Bartholin's gland adenoma; there is moderate intratumoral immunoreactivity to ki-67. Immunoperoxidase, Bar= $50 \mu \mathrm{m}$.

\section{ACKNOWLEDGEMENTS}

The authors thank the following Brazilian Institutes for financial support: Conselho Nacional de Desenvolvimento Científico e Tecnológico (CNPq), the Coordenação de Aperfeiçoamento de Pessoal de Nível Superior (CAPES), Financiadora de Estudos e Projetos (FINEP), and the Araucaria Foundation (FAP/PR). T.E.S. Oliveira, J.P.E. Saut, and S.A. Headley are recipients of CNPq Fellowships. J.P.E. Saut, and S.A. Headley, are recipients of $\mathrm{CNPq}$ grants.

\section{REFERENCES}

BACHA, W. J. \& WOOD, L. M. Female Reproductive System. In: (Ed.). Color Atlas of Veterinary Histology. USA: Williams \& Wilkins, 1990. cap. 18, p.207-229.

BADEMKIRAN, S. et al. Unilateral Bartholin Gland Cyst in A Pregnant Heifer. Journal of the Faculty of Veterinary Medicine, Kafkas University, v. 23, n. 1, p. 61-63, 2009. Available from:
$<$ http://veteriner.fusabil.org/pdf/pdf FUSABIL 637.pdf $>$. Accessed: Dec. 12, 2016.

CARDOSI, R. J. et al. Bartholin's gland carcinoma: a 15-year experience. Gynecologic Oncology, v. 82, n. 2, p. 247-251, 2001. Available from: <https:/www.sciencedirect.com/science/article/ pii/S0090825801963048>. Accessed: Mar. 01, 2017. doi: 10.1006/ gyno.2001.6304.

CARVALHO, M. I. et al. Ki-67 and PCNA expression in canine mammary tumors and adjacent nonneoplastic mammary glands: Prognostic impact by a multivariate survival analysis. Veterinary Pathology, v. 53, n. 6, p. 1138-1146, 2016. Available from: <https://www.ncbi.nlm. nih.gov/pubmed/27162119>. Accessed: Jan. 22, 2017. doi: $10.1177 / 0300985816646429$.

FATHALLA, M. et al. Case report: Bartholin gland cyst in the cow. Canadian Veterinary Journal, v. 19, n. 12, p. 340, 1978. Available from: <https://www.ncbi.nlm.nih.gov/pmc/articles/ PMC1789440/>. Accessed: Feb. 27, 2017. 
FINAN, M. A. \& BARRE, G. Bartholin's gland carcinoma, malignant melanoma and other rare tumours of the vulva. Best Practice \& Research. Clinical Obstetrics \& Gynaecology, v. 17, n. 4, p. 609-633, 2003. Available from: <http://www.journals. elsevierhealth.com/article/S1521-6934(03)00039-7/references>. Accessed: Apr. 03, 2017. doi: 10.1016/S1521-6934(03)00039-7.

GAMEEL, A. A. et al. Ectopic mammary tissue in the vulva of goats. Journal of Veterinary Medicine Series A, v. 39, n. 6, p. 470-475, 1992. Available from: <http://onlinelibrary.wiley.com/ doi/10.1111/j.1439-0442.1992.tb00205.x/full>. Accessed: Apr. 04 2017. doi: 10.1111/j.1439-0442.1992.tb00205.x.

HELLER, D. S. \& BEAN, S. Lesions of the Bartholin gland: a review. Journal of Lower Genital Tract Disease, v. 18, n. 4, p. 351-357, 2014. Available from: <http://journals.lww.com/jlgtd/ Abstract $/ 2014 / 10000 /$ Lesions_of the_Bartholin_Gland_A Review.15.aspx $>$. Accessed: Mar. 02, 2017. doi: 10.1097/ LGT.0000000000000016.

LEE, M. Y. et al. Clinical pathology of Bartholin's Glands: a review of the literature. Current Urology, v. 8, n. 1, p. 22-25, 2015. Available from: <https://www.ncbi.nlm.nih.gov/pmc/articles/ PMC4483306/>. Accessed: Feb. 27, 2017. doi: 10.1159/000365683

LEUCHTER, R. S. et al. Primary carcinoma of the Bartholin gland: a report of 14 cases and review of the literature. Obstetrics and Gynecology, v. 60, n. 3, p. 361-368, 1982. Available from: $<$ http://journals.lww.com/greenjournal/Abstract/1982/09000/ Primary_Carcinoma_of_the_Bartholin_Gland_A_Report.20. aspx>. Accessed: Jan. 22, 2017.

MANOKARAN, S. et al. Unilateral Bartholin's gland cyst in a Holstein Friesian crossbred cow. International Journal of Livestock Research, v. 4, n. 9, p. 48-50, 2014. Available from:
$<$ http://www.scopemed.org/?mno=166568>. doi: 10.5455/ ijlr.20141120091023. Accessed: Dec. 08, 2016.

OMOLE, F. et al. Management of Bartholin's duct cyst and gland abscess. American Family Physician, v. 68, n. 1, p. 135-140, 2003. Available from: <http://www.aafp.org/afp/2003/0701/p135. html>. Accessed: Jan. 22, 2017.

SANTOS, L. D. et al. Nodular hyperplasia of Bartholin's gland. Pathology, v. 38, n. 3, p. 223-228, 2006. Available from: $<$ https://www.sciencedirect.com/science/article/ pii/S0031302516339393>. Accessed: Dec. 18, 2016. doi: $10.1080 / 00313020600696223$.

SCHLAFER, D. H. \& FOSTER, R. A. Female genital system. In: MAXIE, M. G. (Ed.). Jubb, Kennedy, and Palmer's Pathology of domestic animals. St. Louis, Missouri: Elsevier, v.3, 2016. cap. 4, p.358-464.

SOŚNIK, H. et al. The pathomorphology of Bartholin's gland. Analysis of surgical data. Polish Journal of Pathology, v. 58, n. 2, p. 99-103, 2007. Available from: <https://www.ncbi.nlm.nih.gov/ pubmed/17715676> Accessed: Dec. 08, 2016.

TANIMOTO, T. et al. Adenocarcinoma of the major vestibular gland in a cow. Veterinary Pathology, v. 31, n. 2, p. 246-247, 1994. Available from: <http://journals.sagepub. com/doi/pdf/10.1177/030098589403100212>. Accessed: Dec. 08, 2016.

WILKINSON, E. J. \& TEIXEIRA, M. R. Tumours of the vulva In: TAVASSOLI, F. A. e DEVILEE, P. (Ed.). World Health Organization Classification of Tumours of the Breast and Female Genital Organs. Lyon, France: IARCPress, 2003. cap. 7, p.313-334. 